\title{
GENOME-WIDE CHARACTERIZATION OF DROUGHT-RESPONSIVE GENES ACCELERATES FABA BEAN BREEDING PROGRAM
}

\author{
Ewas, Mohamed ${ }^{1 *}$, Sayed A. Omar ${ }^{2}$, Eman El-Serag ${ }^{3}$, Mohamed H. \\ Mubarak $^{3}$ \\ ${ }^{1}$ Genetics and Cytology Unit, Department of Genetic Resources, Desert \\ Research Center, El-Matareya, Cairo, Egypt \\ ${ }^{2}$ Plant Breeding Unit, Department of Genetic Resources, Desert \\ Research Center, El-Matareya, Cairo, Egypt \\ ${ }^{3}$ Department of Crop Production, Faculty of Agriculture, Al-Arish \\ University, Egypt \\ "E-mail: Mohamed82@webmail.hzau.edu.cn \\ Mohamed_ewas82@yahoo.com
}

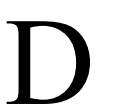

rought is an influential environmental stress that limits faba bean growth and development, leading to a substantial reduction in their productivity in both arid and semi-arid region of the world. However, the responses of faba bean to drought have not been illustrated very well at molecular level. Six cultivars of faba beans and their fifteen hybrids in $\mathrm{F}_{2}$ were used to investigate the transcriptome, proteome, and metabolome changes. In the present study, two-weeks-old seedlings were deficit by seven days drought stress, whereas control seedlings were watered regularly. The results indicated that water deficiency negatively influences substantial physiological and metabolic parameters in faba bean crop. Under drought stress, values of biomass and chlorophyll in the genotypes Nubaria 1, Giza 2, Giza 429, Giza 716, Nubaria $1 \times$ Giza 716, Sakha $2 \times$ Giza 2, Sakha $2 \times$ Giza 716, Giza $2 \times$ Giza 429 and Sakha $2 \times$ Sakha 1 were higher than those of the rest of genotypes. Notably, a marked increase was recorded in the biomolecule indicators of plant oxidative stresses; proline and soluble sugars with same genotypes after water deficiency. Transcriptome analysis via real-time reverse transcriptase-polymerase chain reaction revealed that expression levels of VfDHN4, APETALA2, VfHSP18, and VfAQP2 genes were altered in response to drought conditions. The results demonstrated that all genes were differentially expressed in the studied faba bean genotypes due to water shortage intensity according to cultivar's tolerance to drought. This study could be a distinctive strategy to

The $1^{\text {st }}$ Scientific Conference of Plant Genetic Resources Department, Ecology and Dry Lands Agriculture Division, Desert Research Center "Plant Genetic Resources and Sustainable Development Under Egyptian Desert Conditions" 13-16 November, 2019, Sharm El-Sheikh, South Sinai, Egypt 
speed up breeding programs via exploring the molecular, biochemical and physiological mechanism of drought tolerance in faba bean or other economically important crops.

Keywords: faba bean, drought stress, proteomic, metabolomic, genomic and transcriptomic

The growing population explosion is in dire need of increasing global food production. As water is the source of life, it is the main factor in agricultural expansion to increase food production, particularly in dry and semi-arid lands (Ammar et al., 2017). One of the important food sources is faba bean (Vicia faba L.), especially in Egypt and the Middle East, due to its high nutritional value because it contains high protein and carbohydrates. That is why faba bean ranks fourth among the legume crops after dry beans, dry peas and chickpeas (Toker et al., 2007). Despite the importance of faba bean, the expansion of this crop in Egypt is unstable due to the water deficit, especially in the desert lands which constitute $96 \%$ of the total area of Egypt (Rasmy et al., 2010).

Continuous exposure to drought stress leads to a decline in the yield of faba bean crop due to the increased rate of cellular damage, decreased photosynthesis and the increased accumulation of reactive oxygen species (Belal et al., 2009 and Ewas et al., 2017a). Drought stress restricts plant growth by negatively affecting diverse biochemical and physiological processes, including antioxidant phenomena, osmolyte accumulation, photosynthesis, ion homeostasis and nitrogen metabolism (Ashraf, 2004; Ammar et al., 2017 and Ewas et al., 2017b). For proper growth and water uptake, plants must maintain their relative water content below the soil water content. This mechanism demands the increase of osmotica through improving the synthesis of compatible solutes (Tester and Davenport, 2003 and Dawood et al., 2014).

At the molecular level, many genes play an important role in improving the plant's ability to face drought stress conditions, by increasing the synthesis of various compounds associated with enduring water shortages, controlling of stomatal closure, reducing transpiration rate, eliminating damaging compounds arising from exposure to drought and regulating many important biological processes that protect the plant from environmental stresses (Pastori and Foyer, 2002; Azevedo et al., 2011 and Nagahatenna et al., 2015). Several genes that express under water deficit conditions are implicated in the regulation of all these processes and pathways. In the last decade, many drought-tolerant genes have been reported in main food crops and still there are different genes taking part in drought stress whose functions are unrecognized. The available knowledge about genomic and transcriptomic data provides an essential and quick breakthrough towards exploring the 
functions for many of these unknown genes under various abiotic stresses (Azevedo et al., 2011; Mohamed and Akladious, 2014 and Singh et al., 2018).

Among these genes, dehydrins (Dhn), APETALA2/ethyleneresponsive factors $(A P 2 / E R F S)$, heat shock protein $(H S P)$, and aquaporin $(A Q P s)$ genes are induced in response to drought conditions. Dehydrins $(D H N s)$ proteins play a substantial role in plant adaptation and response to abiotic stresses. They accumulate typically in maturing seeds or are induced in the vegetative tissues following dehydration, salinity, and cold stresses (Close, 1996 and 1997; Svensson et al., 2002; Mouillon et al., 2008; Brini et al., 2010 and Hanin et al., 2011).

Other transcription factors (TFs) like $A P 2 / E R F S$ are an integral component of these signaling cascades, because they regulate expression of a wide variety of down-stream target genes related to stress response and development via different mechanisms (Phukan et al., 2017). The induction of $A P 2 / E R F s$ in response to drought stress have been reported in different plant species including, Pennisetum glaucum (Agarwal et al., 2007), Arabidopsis thaliana (Buttner and Singh, 1997; Bethke et al., 2009; An et al., 2010 and Bolt et al., 2017), Eucalyptus grandis (Cao et al., 2015), Solanum tuberosum (Charfeddine et al., 2015) and Medicago sativa (Chen et al., 2012).

Heat-shock proteins $(H S P S)$ work as molecular chaperones for a variety of client proteins in abiotic stress response and play central roles in protecting plants against stress (Xiang et al., 2018). HSP proteins are large gene family that are up-regulated by heat stress and positively regulates drought stress tolerance perhaps by modulating osmotic adjustment and ROS homeostasis in many crops such as rice (Boston et al., 1996; Apel and Hirt, 2004; Breiman, 2014; Fang et al., 2015 and Xiang et al., 2018), tomato (Hahn et al., 2011) and soybean (Xu et al., 2013).

Aquaporin proteins $(A Q P s)$ are present in several isoforms in both tonoplast membranes and plasmalemma to control water flow in and out of plant cells. Thus, it is not unusual that molecular and physiological studies have reported $A Q P S$ as playing pivotal roles in regulating hydraulic conductance in leaves and roots. Consequently, $A Q P S$ activation influences a group of physiological processes including phloem Absorbing, xylem water egression, gas exchange and stomatal closure (Shekoofa and Sinclair, 2018).

The present study reveals the possibility of accelerating faba bean breeding programs for drought tolerance by studying the transcript level of many drought-tolerance-related-genes such as Dhn, APETALA2/ERFs, HSP and $A Q P$ proteins. The induction of these genes improves various physiological processes in faba bean, including the increased of proline, chlorophyll and soluble sugars synthesis, as well as the production of several proteins that increase drought tolerance. This study could be distinctive and useful in crop breeding programs to improve many other important crops. 


\section{MATERIALS AND METHODS}

\section{Plant Materials and Growth Condition}

Seeds of twenty-one genotypes of faba bean including six cultivars (Nubaria 1, Sakha 1, Sakha 2, Giza 2, Giza 429 and Giza 716) and its fifteen hybrids in $\mathrm{F}_{2}$ were used in the experiments of the present study (Supplemental Table S1). All genotypes were grown in a greenhouse under a $12 \mathrm{~h}$ light/12 h dark regime of $180 \mathrm{mmol} \mathrm{m}^{-2} \mathrm{~s}^{-1}$ light intensity (Qian et al., 2015).

\section{Physiological Measurements}

For physiological studies, two-weeks-old seedlings were deficit by seven days of drought stress, whereas control seedlings were watered regularly. After treatment, seedlings were weighed (fresh weight) and dried in an oven at $70^{\circ} \mathrm{C}$ for $48 \mathrm{~h}$ then weighed (dry weight). Soluble sugars, chlorophyll (A and B) and proline contents were measured with three replicates, according to the previous methods described by Bates et al. (1973), Wellburn (1994) and Orozoco and Ryan (1999). Meanwhile, the total carotenoids content was determined in $0.1 \mathrm{~g}$ fresh tissue of leaves using Spekol 11 spectrophotometer following the method of Metzner et al. (1965).

\section{Biochemical Analysis}

Total protein was extracted from bulk-crushed leaves as described by Chen et al. (1995). Then powder $(0.05 \mathrm{~g})$ was soaked in $0.4 \mathrm{ml}$ water for at least $24 \mathrm{~h}$, and then the mixture was placed in an Eppendorf centrifuge for 30 min at $8000 \mathrm{~g}$. The supernatant was preserved at $4^{\circ} \mathrm{C}$ for sample preparation. Each sample was suspended in a medium containing 2\% SDS (w/v), 5\% 2mercaptoethanol (w/v), $0.001 \%$ pyronin $(\mathrm{w} / \mathrm{v}), 10 \%$ glycerol $(\mathrm{v} / \mathrm{v})$, and $1 \mathrm{M}$ Tris- $\mathrm{HCl}, \mathrm{pH}$ 6.8. The samples were left for $3 \mathrm{~h}$ at room temperature and shaken every $15 \mathrm{~min}$. Then, the mixture was placed in a boiling water bath for 3-5 min and cooled at $4^{\circ} \mathrm{C}$. Sodium dodecyl sulphate polyacrylamide gel electrophoresis (SDS-PAGE) was performed on $4 \%$ slab gels in a discontinuous buffer system as described by Laemmli (1970). A constant electric current of $30 \mathrm{~mA}$ was used to run two gels for $10 \mathrm{~h}$.

\section{Expression Analyses}

Total RNA was extracted using Trizol reagent (Invitrogen), while the first-strand cDNA was synthesized using 200 U of M-MLV reverse transcriptase (Invitrogen) and $3 \mu \mathrm{g}$ of RNA according to the producer's protocol. Real-time Polymerase Chain Reaction (PCR) was carried out on an optical 96-well plate using an AB StepOnePlus PCR system (Applied Biosystems) by using SYBR Premix Reagent F-415 (Thermo Scientific). Also, actin gene was used as an internal control which was amplified with 24 cycles. Gene expression level was calculated using a relative quantification 
method described by Schmittgen and Livak (2008). All primers used in this study are shown in supplemental table (S2).

\section{RESULTS AND DISCUSSIONS}

\section{Physiological Changes in Faba Bean Genotypes as a Response to Drought Stress}

Drought is one of the most severe stresses that negatively affect various physiological processes in the plant including biomass, chlorophyll, soluble sugars and proline synthesis. In the present study, seedlings of twentyone genotypes of faba bean, including six cultivars and their fifteen hybrids at two-weeks old were exposed to drought stress for seven days. The results show that the negative impact of drought stress depends on the ability of faba bean genotypes to endure this stress. This idea was confirmed by the results of biomass analysis, which showed a significant decrease in both fresh and dry weights for all genotypes except Nubaria 1, Giza 2, Giza 429, Giza 716, Nubaria $1 \times$ Giza 716, Sakha $2 \times$ Giza 2, Sakha $2 \times$ Giza 716, Giza $2 \times$ Giza 429 and Sakha $2 \times$ Sakha 1 under drought conditions, while no significant differences were recorded between all genotypes under normal conditions (Fig. 1).

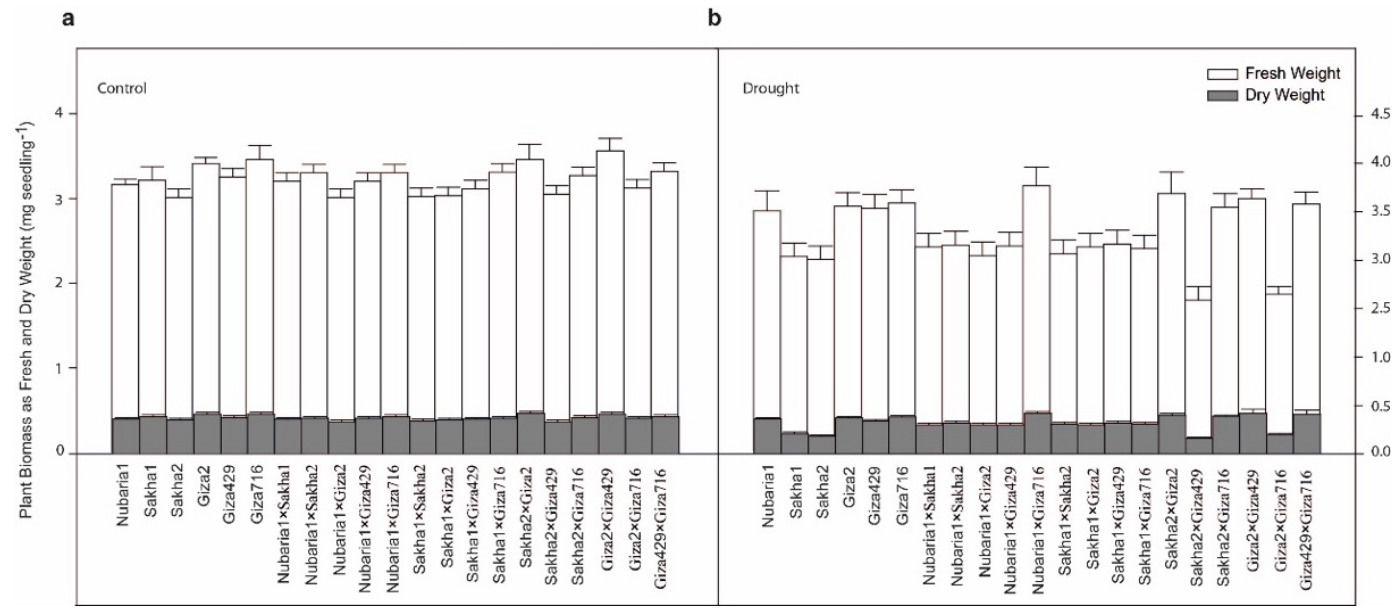

Fig. (1). Drought stress affects the biomass of faba bean genotypes. (a) Plant biomass under normal conditions; (b) Plant biomass under drought stress conditions. Fresh and dry weights were measured to obtain plant biomass $\left(\mathrm{mg}\right.$ seedling $\left.{ }^{-1}\right)$. Values are the mean $\pm \mathrm{SD}(\mathrm{n}=8)$.

The association of growth performance with genotype in response to drought stress has been reported in several plant species such as maize, rice, potato and tomato (Yan et al., 2000; Sarma et al., 2016; Shahzad et al., 2016 and Ewas et al., 2017a and b). 
In relation to growth, the photosynthetic active pigments, chlorophylls a and $\mathrm{b}$ of plant leaves decreased significantly with the continued effect of drought stress for all genotypes except Nubaria 1, Giza 2, Giza 429, Giza 716, Nubaria $1 \times$ Giza 716, Sakha $2 \times$ Giza 2, Sakha $2 \times$ Giza 716, Giza $2 \times$ Giza 429 and Sakha $2 \times$ Sakha 1 (Fig. 2a, b), while no significant differences were registered between all genotypes under normal conditions (Fig. 2c, d). In the same manner, a marked increase in the total carotenoids content was detected in the leaves of the same genotypes characterized by higher chlorophyll content than the rest of the studied genotypes under drought stress conditions. However, there was no significant difference in the total carotenoids content among all faba bean genotypes under normal conditions (Fig. 2e, f). Working with algae, it has been found that exposure to dehydration stress also reduced the photosynthetic pigments content (Karsten and Holzinger, 2011 and $\mathrm{Wu}, 2016)$. The synthesis level of chlorophyll a and $\mathrm{b}$ rely on the ability of the genotype to cope with drought stress, this idea was confirmed previously in different plant species including, Triticum aestivum (Rahnama et al., 2010), Oryza sativa (Moonmoon et al., 2017), Solanum lycopersicum (Zhou et al., 2017) and Arabidopsis thaliana (Yao et al., 2018).

Soluble sugars changed dramatically between faba bean genotypes in the present study. The soluble sugars content decreased slightly in all genotypes, except the same genotypes that had higher biomass rates and pigments under drought stress conditions, including Nubaria 1, Giza 2, Giza 429, Giza 716, Nubaria $1 \times$ Giza 716, Sakha $2 \times$ Giza 2, Sakha $2 \times$ Giza 716, Giza $2 \times$ Giza 429 and Sakha $2 \times$ Sakha 1, also had high soluble sugars content (Fig. 3). These findings are consistent with the results of distinctive droughtprone genotypes, including faba beans (Belal et al., 2009), soybean (Mohamed and Latif, 2017), tomato, maize (Nayer and Heidari, 2008), rice (Rebolledo et al., 2012), wheat (Marcek et al., 2019) and barley (Wehner et al., 2015).

On the other hand, the results of proline accumulation analysis showed a slight increase of proline content in leaves of all faba bean genotypes after exposure to drought stress, except for Nubaria 1, Giza 2, Giza 429, Giza 716, Nubaria $1 \times$ Giza 716, Sakha $2 \times$ Giza 2, Sakha $2 \times$ Giza 716, Giza $2 \times$ Giza 429 and Sakha $2 \times$ Sakha 1, which exhibited a marked increase in proline accumulation level under drought stress condition (Fig. 4b). However, no significant differences were recorded in the proline content between all investigated faba bean genotypes under normal conditions (Fig. 4a). These results are in close agreement with those obtained by some researchers (Xiong et al., 2012; Bandurska et al., 2017 and Fu et al., 2018).

Positive correlation between increased ABA levels and proline accumulation in plants and environmental stresses that lead to limit plant growth was reported by Do"rffling et al. (1990) and Yashiba et al. (1997). Under drought stress, a common effect of prevent irrigation and water loss from plants is the accumulation of ABA (Loukehaich et al., 2012). The significance of proline accumulation due to drastic environmental factors is Egyptian J. Desert Res., 69, Special Issue, 47-67 (2019) 
still controversial (Verma and Hong, 1996 and Hare and Cress, 1997), and other functions have been suggested for this response such as nitrogen storage, free radical scavenging or $\mathrm{pH}$ regulation (Stewart and Hanson 1980). Thus, proline accumulation in response to stress conditions is still challenge not only in the discussions reported previously, but also in the current study.

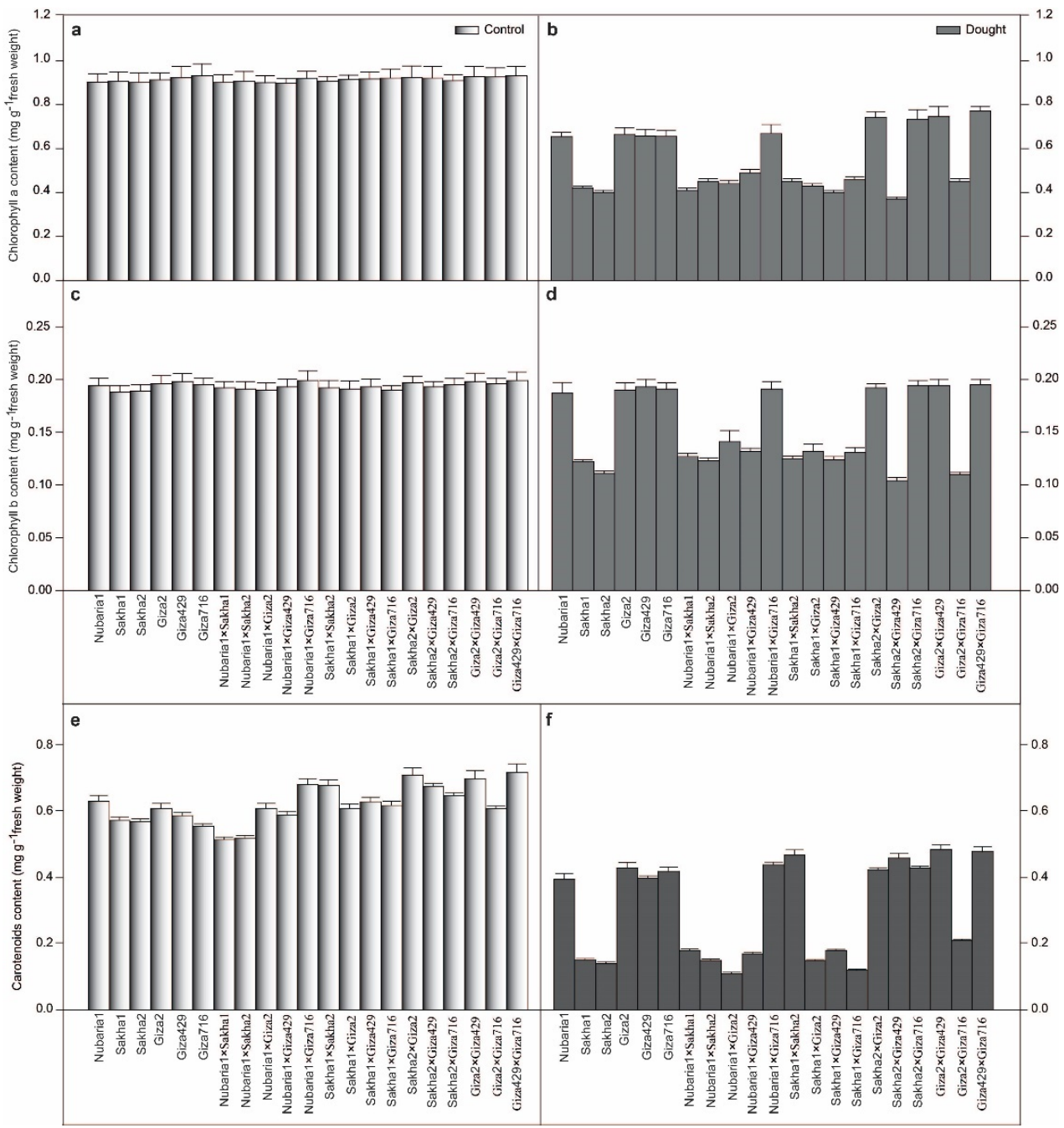

Fig. (2). Drought stress affects the pigments content (mg seedling $\left.{ }^{-1}\right)$ of faba bean genotypes. (a) Chlorophyll a content under normal conditions; (b) Chlorophyll a content under drought stress conditions; (c) Chlorophyll b content under normal conditions; (d) Chlorophyll b content under drought stress conditions; (e) Carotenoids content under normal conditions; (f) Carotenoids content under drought stress conditions. Values are the mean $\pm \mathrm{SD}(\mathrm{n}=8)$.

Egyptian J. Desert Res., 69, Special Issue, 47-67 (2019) 


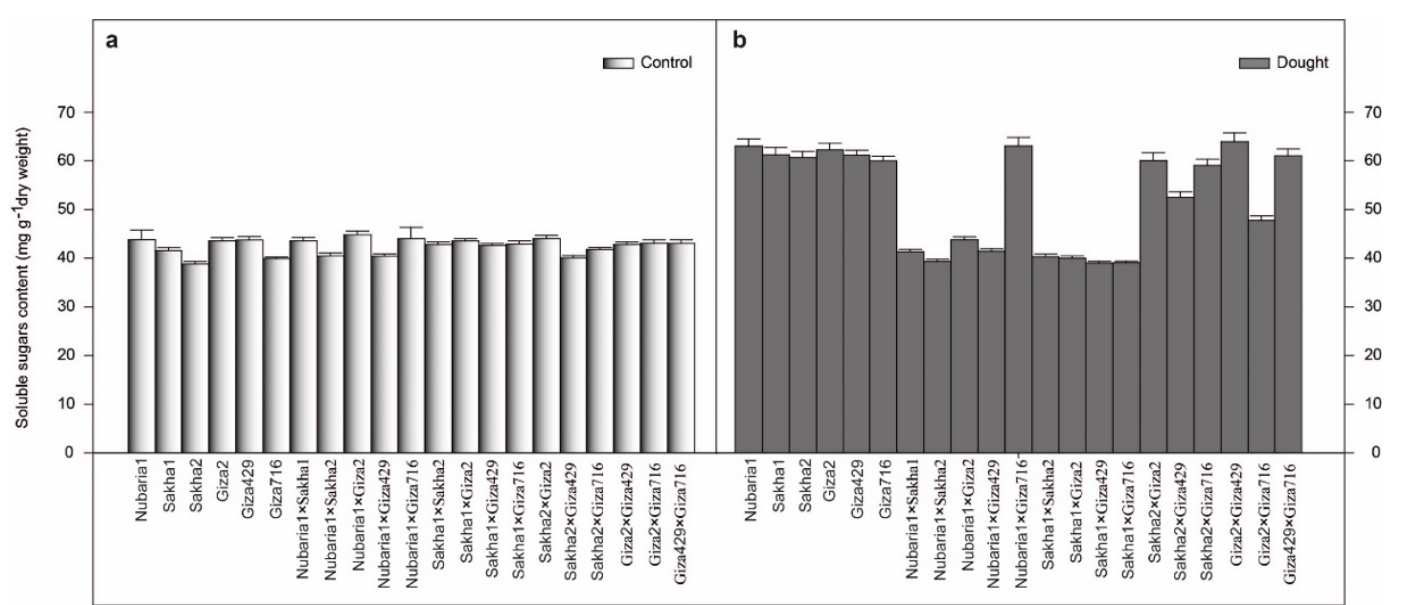

Fig. (3). Drought stress affects soluble sugars content ( $\mathrm{mg} \mathrm{g}^{-1}$ dry weight) of faba bean genotypes. (a) Soluble sugars content under normal conditions; (b) Soluble sugars content under drought stress conditions. Values are the mean $\pm \mathrm{SD}(\mathrm{n}=8)$.

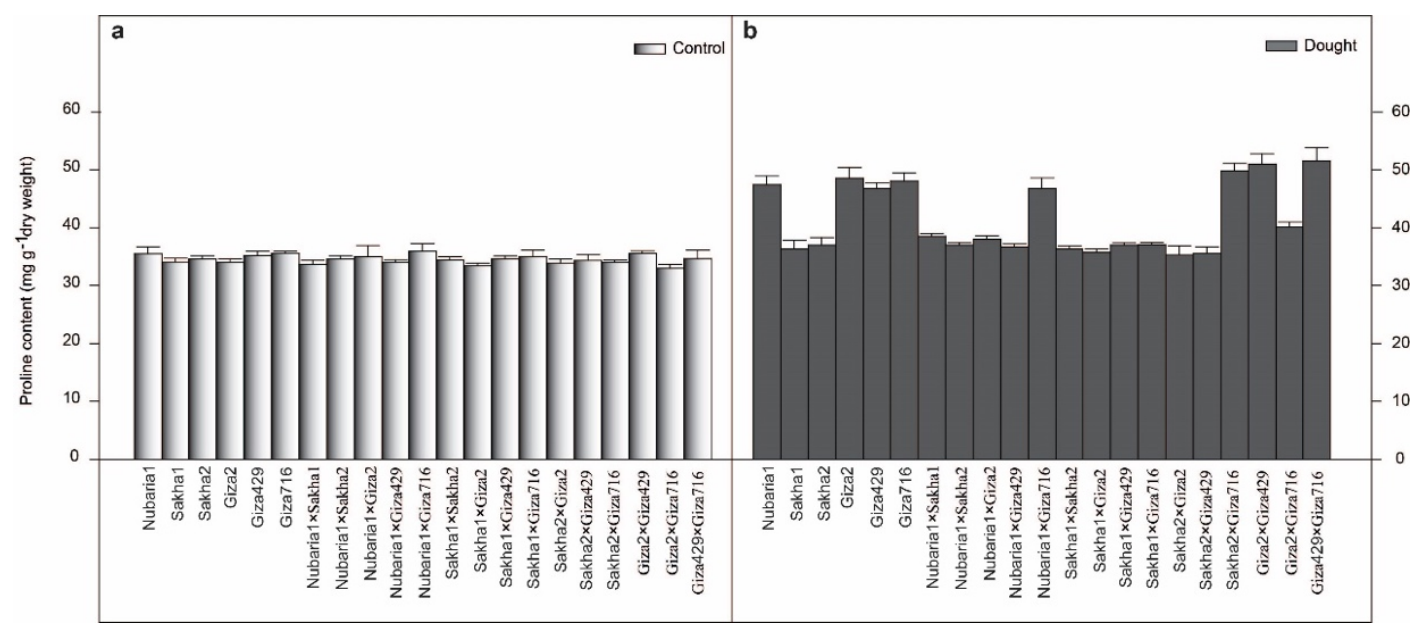

Fig. (4). Drought stress affects proline content ( $\mathrm{mg} \mathrm{g}^{-1}$ dry weight) of faba bean genotypes. (a) Proline content under normal conditions; (b) Proline content under drought stress conditions. Values are the mean $\pm \mathrm{SD}(\mathrm{n}=$ 8).

\section{Biochemical Changes in Faba Bean Genotypes as a Response to Drought Stress}

Sodium dodecyl sulphate polyacrylamide gel electrophoresis (SDSPAGE) is widely used to fractionate the proteins according to their molecular weights (Sharobeen et al., 1991). In order to study the variation of the studied genotypes in response to drought stress, protein extracts were analyzed by

Egyptian J. Desert Res., 69, Special Issue, 47-67 (2019) 
SDS-PAGE. The analysis showed induction of $\sim 15,20,35,45,80$ and 120 $\mathrm{kDa}$ proteins under stress condition, which could be used as a positive markers of drought tolerance (Fig. 5). These results also reveal that the drought tolerant and susceptible genotypes of faba bean differed from each other in their protein patterns and each of them characterized by the presence of some specific protein bands. Robinson et al. (1990) suggested that the disappearance of polypeptides during stress were compensated by the increased synthesis of others. Moreover, under drought stress, despite the reduction in protein levels (Singla and Grover, 1994), the cells preferentially synthesized a few specific proteins that are termed stress proteins (Pureek et al., 1995).

\section{Differential Expression of the Genes Involved in Responses to Water- Deficit Stress in Faba Bean Genotypes}

At the molecular level, plants regulate the expression of stresstolerance-related genes to cope with different stresses. Previous studies identified Dhns, APETALA2/ERFs, HSPS and AQPS gene-families as induced proteins under drought stress conditions (Hanin et al., 2011; Cao et al., 2015; Xiang et al., 2018 and Shekoofa and Sinclair, 2018). To further explore the molecular response to drought stress in faba bean genotypes, the expression level of VfDHN4 was measured in the leaves of investigated faba bean genotypes under normal and drought stress conditions. No significant differences were recorded in the expression level of all genotypes (Fig. 6a), while a marked induction of $V f D H N 4$ was recorded after preventing irrigation for seven consecutive days, especially in leaves of Nubaria 1, Giza 2, Giza 429, Giza 716, Nubaria $1 \times$ Giza 716, Sakha $2 \times$ Giza 2, Sakha $2 \times$ Giza 716, Giza $2 \times$ Giza 429 and Sakha $2 \times$ Sakha 1 up to 11.07, 12.71, 13.47, 12.52, $13.52,13.31,13.03,14.00,14,32$, respectively (Fig. 6b). A previous study indicated that $D H N 4$ is regulated by an ABA-dependent signal pathway and that the high sensitivity of VfDHN4 to ABA might be an important mechanism enhancing the drought tolerance of faba bean (Lv et al., 2017).

Similar to the results of $V f D H N 4$ gene expression, there were no significant differences in the gene expression of both VFAPETALA2 and VfHSP18 among all faba bean genotypes under normal conditions (Fig. 6c, e). Under drought stress conditions, the transcript levels of VfAPETALA2 and VfHSP18 were up-regulated in leaves of Nubaria 1, Giza 2, Giza 429, Giza 716, Nubaria $1 \times$ Giza 716, Sakha $2 \times$ Giza 2, Sakha $2 \times$ Giza 716, Giza $2 \times$ Giza 429 and Sakha $2 \times$ Sakha 1 up to $2.77,3.01,2.95,2.84,3.21,3.51,2.84$, 3.22 and 3.02, and 2.10, 2.22, 2.31, 2.12, 2.41, 2.50, 2.43, 2.36 and 2.51, respectively (Fig. 6d, f). Heat shock proteins HSPs and APETALA2/ERFs function as molecular chaperones. These proteins are encoded by multi-gene families, whose members play crucial roles in plant growth, development and 
stress response (Okamuro et al., 1997; Nagaya et al., 2009; Mustari et al., 2016; Chen et al., 2018 and Lin et al., 2018).

a

b
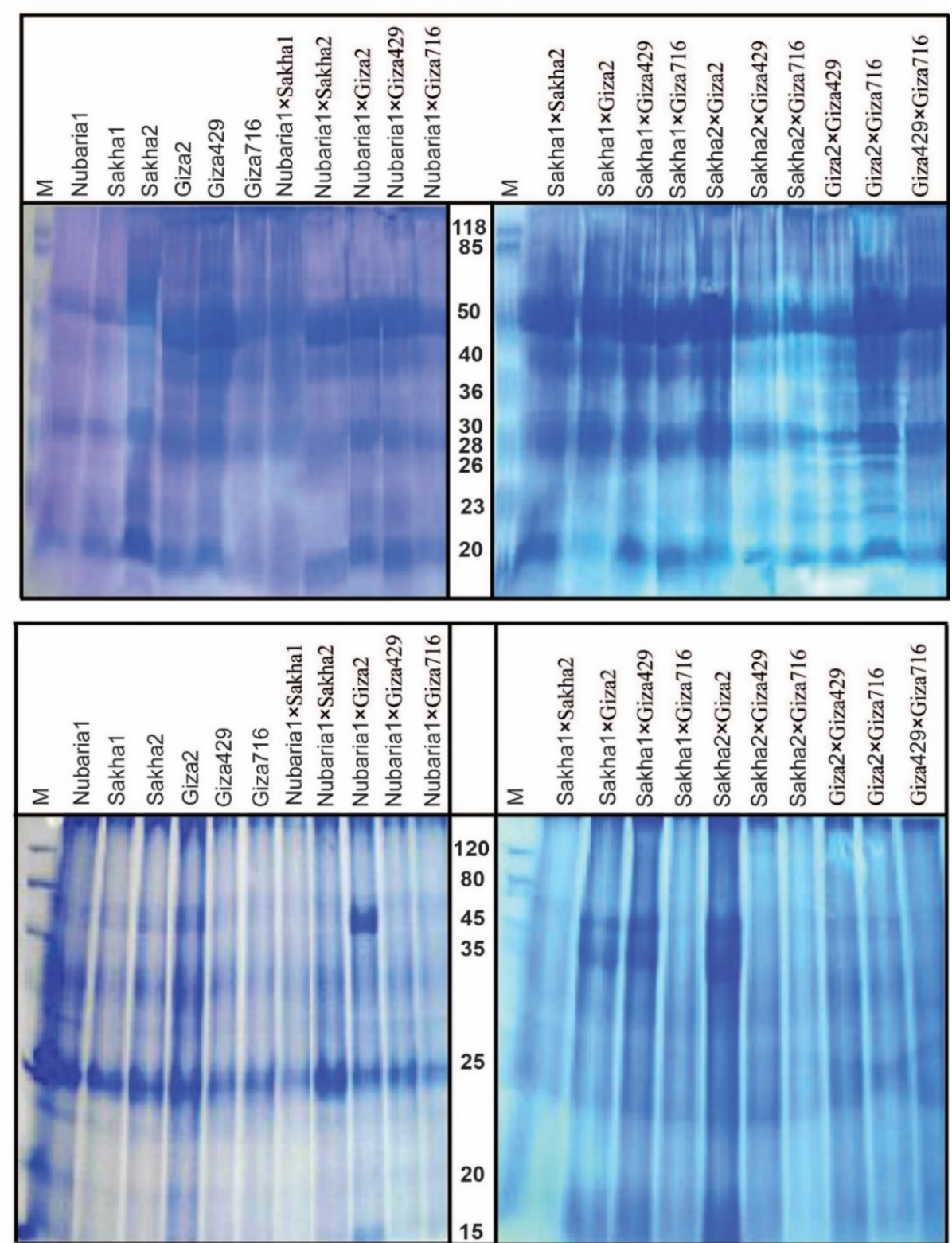

Fig. (5). Drought stress affects faba bean proteome. (a) Electrophoretic profiles of total proteins of parental and $\mathrm{F}_{2}$ genotypes of faba bean under normal condition; (b) Electrophoretic profiles of total proteins of parental and $\mathrm{F}_{2}$ genotypes of faba bean under stress condition.

Egyptian J. Desert Res., 69, Special Issue, 47-67 (2019) 


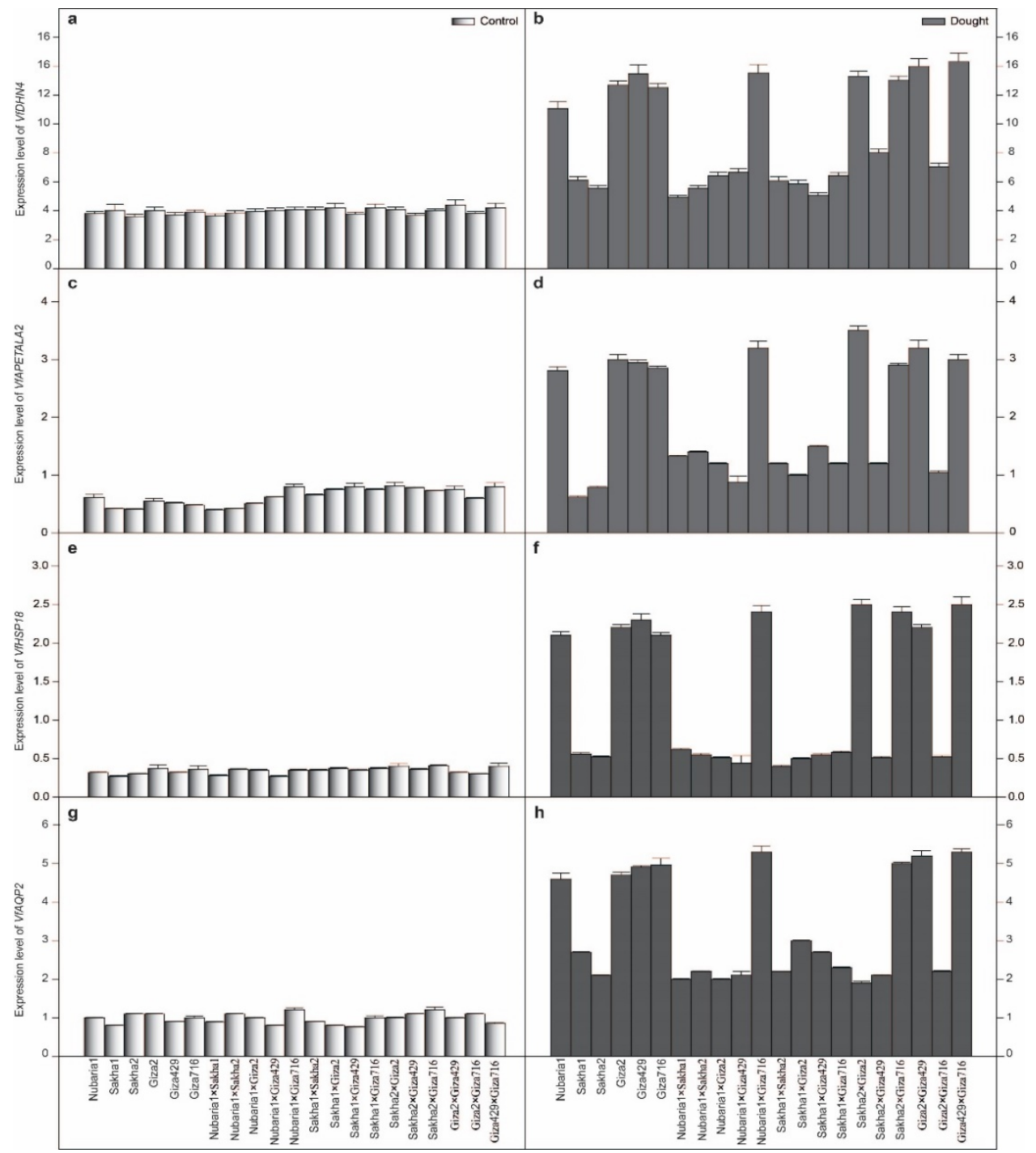

Fig. (6). Real-time quantitative PCR analysis for the transcripts of key genes involved in drought-stress tolerance. (a and b) Expression level of $V f D H N 4$ under normal and drought stress conditions, respectively; (c and d) Expression level of VfAPETALA2 under normal and drought stress conditions, respectively; (e and f) Expression level of VfHSP 18 under normal and drought stress conditions, respectively; (g and $\mathbf{h}$ ) Expression level of $V f A Q P 2$ under normal and drought stress conditions, respectively. Actin was used as an internal control. Data are means of three biological replicates and error bars are \pm SE from three independent experiments, each performed with 6-8 leaves from five separate plants.

Egyptian J. Desert Res., 69, Special Issue, 47-67 (2019) 
In agreement with the results of transcript analysis of VfDHN4, VAAPETALA2 and VFHSP18 under normal conditions, no significant differences were obtained in the expression level of $V f A Q P 2$ among all studied faba bean genotypes (Fig. 6g). Conversely, a marked induction of VfAQP2 was registered after preventing irrigation for seven days, especially in leaves of Nubaria 1, Giza 2, Giza 429, Giza 716, Nubaria $1 \times$ Giza 716, Sakha $2 \times$ Giza 716, Giza $2 \times$ Giza 429 and Sakha $2 \times$ Sakha 1 up to 4.62, 4.71, 4.90, 4.96, 5.3, 5.00, 5.21 and 5.32, respectively (Fig. 6h). Aquaporins are membrane channels that facilitate the transport of water and small neutral molecules across biological membranes of most living organisms. In plants, aquaporins occur as multiple isoforms reflecting a high diversity of cellular localizations, transport selectivity, and regulation properties (Maurel et al., 2015). Induction of the aquaporin proteins (AQPs) under drought stress (Satake et al., 2010) has been reported previously in different plant species including, strawberry (Alleva et al., 2010), Beta vulgaris (Alleva et al., 2006), maize (Aroca et al., 2005) and Phaseolus vulgaris (Aroca et al., 2006).

\section{CONCLUSION}

In conclusion, drought stress impacts cell metabolism of economic crops, specifically their photosynthetic machinery. In the present study, several drought-responsive genes and genotypic differentially expressed genes between genotypes were analyzed by the real-time PCR approach using twenty-one faba bean genotypes with contrasting drought tolerance. Different regulation patterns and functional enrichment of these genes between the tolerant and sensitive genotypes were obtained. The results of gene expression were consistent with those of physiological and biochemical analyses, including the values of biomass, soluble sugars, chlorophyll, carotenoids, proline and peptides. The results of the present study help to elucidate the drought-responsive molecular mechanisms and provide candidate genes for further study to improve drought tolerance in faba bean breeding program.

\section{ACKNOWLEDGMENT}

The authors would like to thank Prof. Luo Jie and Prof. Ali El-Hosary for their technical support to the research; Dr. Eman Khames for advice and suggestions. The authors also extend their gratitude to Desert Research Center, Al-Arish University and Tanta University, Egypt, for providing the opportunity to pursue this study.

Egyptian J. Desert Res., 69, Special Issue, 47-67 (2019) 
Table (S1). Names, origin, pedigree and features of the twenty-one faba bean genotypes.

\begin{tabular}{|c|c|c|c|}
\hline Genotype & Origin & Pedigree & Features \\
\hline Nubaria $_{1}$ & FCRI & $\begin{array}{l}\text { Individual plant selection } \\
\text { from Spanish variety Reina } \\
\text { Blanca }\end{array}$ & $\begin{array}{l}\text { Large-seeded, foliar disease } \\
\text { resistant, colorless-hilum } \\
\text { seed and drought tolerant }\end{array}$ \\
\hline Sakha & FCRI & Reina Blanca×461/845/83 & $\begin{array}{c}\text { Foliar disease resistant and } \\
\text { drought tolerant }\end{array}$ \\
\hline Sakha2 & FCRI & $-716 / 724 / 88 \times 620 / 283 / 85$ & $\begin{array}{l}\text { Early and foliar disease } \\
\text { resistant }\end{array}$ \\
\hline Giza2 & FCRI & $\begin{array}{l}\text { Individual plant selection } \\
\text { from Giza } 402 \text { variety }\end{array}$ & Orbanche resistant \\
\hline Giza429 & FCRI & $461 / 842 / 83 \times 503 / 453 / 83$ & $\begin{array}{l}\text { Early, foliar disease resistant } \\
\text { and drought tolerant }\end{array}$ \\
\hline Giza716 $_{71}$ & FCRI & $\begin{array}{l}\text { Individual plant selection } \\
\text { from local genetic resources }\end{array}$ & Early \\
\hline Nubaria $_{1} \times$ Sakha $_{1}$ & EDGB & Half diallele cross & $F_{2}$ \\
\hline Nubaria $_{1} \times$ Sakha $_{2}$ & EDGB & Half diallele cross & $\mathrm{F}_{2}$ \\
\hline Nubaria $_{1} \times$ Giza $_{2}$ & EDGB & Half diallele cross & $\mathrm{F}_{2}$ \\
\hline Nubaria $_{1} \times$ Giza $_{429}$ & EDGB & Half diallele cross & $\mathrm{F}_{2}$ \\
\hline Nubaria $_{1} \times$ Giza $_{716}$ & EDGB & Half diallele cross & $\mathrm{F}_{2}$ \\
\hline Sakha $\times$ ×Sakha 2 & EDGB & Half diallele cross & $\mathrm{F}_{2}$ \\
\hline Sakha $_{1} \times$ Giza $_{2}$ & EDGB & Half diallele cross & $\mathrm{F}_{2}$ \\
\hline Sakha1× Giza429 & EDGB & Half diallele cross & $F_{2}$ \\
\hline Sakha $1 \times$ Giza716 & EDGB & Half diallele cross & $\mathrm{F}_{2}$ \\
\hline Sakha $_{2} \times$ Giza $_{2}$ & EDGB & Half diallele cross & $\mathrm{F}_{2}$ \\
\hline Sakha $2 \times$ Giza 429 & EDGB & Half diallele cross & $\mathrm{F}_{2}$ \\
\hline Sakha $2 \times$ Giza716 & EDGB & Half diallele cross & $\mathrm{F}_{2}$ \\
\hline Giza $_{2} \times$ Giza429 $_{2}$ & EDGB & Half diallele cross & $\mathrm{F}_{2}$ \\
\hline Giza2 $\times$ Giza 716 & EDGB & Half diallele cross & $\mathrm{F}_{2}$ \\
\hline Giza429 $\times$ Giza716 & EDGB & Half diallele cross & $\mathrm{F}_{2}$ \\
\hline
\end{tabular}

FCRI = Field Crops Research Institute, Agricultural Research Center "ARC", Giza, Egypt. EDGB = Egyptian Desert Gene Bank, Desert Research Center "DRC" North Sinai, Egypt.

Table (S2). Primer pairs used in this study for gene expression analysis.

\begin{tabular}{ccc}
\hline Experiment & Primer Name & Primer Sequence \\
\hline & VfDHN4 $-\mathrm{FW}$ & CATGAGGGACGAGCACCAGACT \\
VfDHN4-RV & GATCTTCTCCTTGATGCCCTTCT \\
& VfAPETALA2-FW & AAGAGGACCATCTCTCAG \\
& VfAPETALA2-RV & AACACTCGCTAGCTTCTC \\
& VfHSP $18-\mathrm{FW}$ & CAAGTTGCCCATCATTACGG \\
& VfHSP $18-\mathrm{RV}$ & TATGCCGGGCACTTTCCCAC \\
Expression & VfAQP2-FW & GCCTCAGGCCCCAATCTAAT \\
analysis & VfAQP2-RV & AGGAGGAGTGTGGAGGGTTT \\
& Actin -FW & AAATGACGCAGATTATGTTTA \\
& Actin -FW & GCTCGTAGTGAGGGAGTACC \\
\hline
\end{tabular}

Egyptian J. Desert Res., 69, Special Issue, 47-67 (2019) 


\section{REFERENCES}

Agarwal, P., P.K. Agarwal, S. Nair, S.K. Sopory and M.K. Reddy (2007). Stress-inducible DREB2A transcription factor from Pennisetum glaucum is a phosphoprotein and its phosphorylation negatively regulates its DNA. Mol. Genet. Genom., 277: 189-198.

Alleva, K., C.M. Niemietz, M. Sutka, C. Maurel, M. Parisi, S.D. Tyerman and G. Amodeo (2006). Plasma membrane of Beta vulgaris storage root shows high water channel activity regulated by cytoplasmic $\mathrm{pH}$ and a dual range of calcium concentrations. J. Exp. Bot., 57: 609-621.

Alleva, K., M. Marquez, N. Villarreal, P. Mut, C. Bustamante, J. Bellati, G. Martínez, M. Civello and G. Amodeo (2010). Cloning, functional characterization, and co-expression studies of a novel aquaporin (FaPIP2;1) of strawberry fruit. J. Exp. Bot., 61: 3935-3945.

Ammar, M.H., A.M. Khan, H.M. Migdadi, S.M. Abdelkhalek and S.S. Alghamdi (2017). Faba bean drought responsive gene identification and validation. Saudi J. Biol. Sci., 24: 80-89.

An, F., Q. Zhao, Y. Ji, W. Li, Z. Jiang, X. Yu et al. (2010). Ethylene-induced stabilization of ETHYLENE INSENSITIVE3 and EIN3-LIKE1 is mediated by proteasomal degradation of EIN3 binding F-box 1 and 2 that requires EIN2 in Arabidopsis. Plant Cell, 22: 2384-2401.

Apel, K. and H. Hirt (2004). Reactive oxygen species: metabolism, oxidative stress, and signal transduction. Annu. Rev. Plant. Biol., 55: 373-399.

Aroca, R., G. Amodeo, S. Fernándezlllescas, E.M. Herman, F. Chaumont and M.J. Chrispeels (2005). The role of aquaporins and membrane damage in chilling and hydrogen peroxide induced changes in the hydraulic conductance of maize roots. Plant Physiol., 137: 341-353.

Aroca, R., A. Ferrante, P. Vernieri and M.J. Chrispeels (2006). Drought, abscisic acid and transpiration rate effects on the regulation of PIP aquaporin gene expression and abundance in Phaseolus vulgaris plants. Ann. Bot., 98: 1301-1310.

Ashraf, M. (2004). Some important physiological selection criteria for salt tolerance in plants. Flora Morphology, Distribution, Functional Ecology of Plants, 199: 361-376.

Azevedo, H., J. Silva-Correia, J. Oliveira et al. (2011). A strategy for the identification of new abiotic stress determinants in Arabidopsis using web-based data mining and reverse genetics. Omics A Journal of Integrative Biology, 15 (12): 935-947.

Bandurska, H., J. Niedziela, M. Pietrowska-Borek, K. Nuc, T. Chadzinikolau and D. Radzikowska (2017). Regulation of proline biosynthesis and resistance to drought stress in two barley (Hordeum vulgare L.) genotypes of different origin. Plant Physiol. Biochem., 118: 427-437.

Egyptian J. Desert Res., 69, Special Issue, 47-67 (2019) 
Bates, L.S., R.P. Waldren and I.D. Teare (1973). Rapid determination of free proline for water-stress studies. Plant Soil, 39: 205-207.

Belal, A., S. Omer, E. El-Sarag and M. El-Metwally (2009). Genetic studies on breeding faba bean for drought tolerance 1- Genetic variations. Catrina, 4: 11-19.

Bethke, G., T. Unthan, J.F. Uhrig, Y. Poschl, A.A. Gust, D. Scheel et al. (2009). Flg22 regulates the release of an ethylene response factor substrate from MAP kinase 6 in Arabidopsis thaliana via ethylene signaling. Proc. Natl. Acad. Sci. U.S.A., 106: 8067-8072.

Bolt, S., E. Zuther, S. Zintl, D.K. Hincha and T. Schmulling (2017). ERF105 is a transcription factor gene of Arabidopsis thaliana required for freezing tolerance and cold acclimation. Plant Cell Environ., 40: 108120.

Breiman, A. (2014). Plant Hsp90 and its co-chaperones. Curr. Protein Pept. Sci., 15: 232-244.

Brini, F., W. Saibi, M. Hanin, I. Amara, A. Gargouri and K. Masmoudi (2010). The wheat dehydrin DHN-5 exerts a heat-protective effect on $\beta$ glucosidase and glucose oxidase activities. Biosci. Biotechnol. Biochem., 74: 1050-1054.

Boston, R.S., P.V. Viitanen and E. Vierling (1996). Molecular chaperones and protein folding in plants. Plant Mol. Biol., 32: 191-222.

Buttner M. and K.B. Singh (1997). Arabidopsis thaliana ethylene-responsive element binding protein $(A t E B P)$, an ethylene-inducible, GCC box DNA-binding protein interacts with an ocs element binding protein. Proc. Natl. Acad. Sci. U.S.A., 94: 5961-5966.

Cao, P.B., S. Azar, H. SanClemente, F. Mounet, C. Dunand, G. Marque et al. (2015). Genome-wide analysis of the AP2/ERF family in Eucalyptus grandis: an intriguing over-representation of stress-responsive DREB 1/CBF genes. PLoS One, 10: e0121041.

Charfeddine, M., M.N. Saidi, S. Charfeddine, A. Hammami and R. Gargouri Bouzid (2015). Genome-wide analysis and expression profiling of the ERF transcription factor family in potato (Solanum tuberosum L.) Mol. Biotechnol., 57: 348-358.

Chen, J., J.W. Farrell, D.W. Murray and W.L. Perl (1995). Oxygen isotope record from the northeast Indian Ocean (Ocean Drilling Program Site 758). Paleoceanography, 10 (1): 21-48.

Chen, T., Q. Yang, M. Gruber, J. Kang, Y. Sun, W. Ding et al. (2012). Expression of an alfalfa (Medicago sativa L.) ethylene response factor gene $M s E R F 8$ in tobacco plants enhances resistance to salinity. Mol. Biol. Rep., 39: 6067-6075.

Chen, J., T. Gao, S. Wan et al. (2018). Genome-wide identification, classification and expression analysis of the HSP gene superfamily in tea plant (Camellia sinensis). Int. J. Mol. Sci., 19 (9): 2633. 
Close, T.J. (1996). Dehydrins: Emergence of a biochemical role of a family of plant dehydration proteins. Physiol. Plant., 97: 795-803.

Close, T.J. (1997). Dehydrins: A commonalty in the response of plants to dehydration and low temperature. Physiol. Plant., 100: 291-296.

Dawood, M.G., H.A.A. Taie, R.M.A. Nassar, M.T. Abdelhamid and U. Schmidhalter (2014). The changes induced in the physiological, biochemical and anatomical characteristics of Vicia faba by the exogenous application of proline under seawater stress. South African Journal of Botany, 93: 54-63.

Do"rffling, K., S. Schulenburg, G. Lesselichc and H. Do“rffling (1990). Abscisic acid and proline levels in cold hardened winter wheat leaves in relation to variety-specific differences in freezing resistance. J. Agron. Crop. Sci., 165 (230): 239.

Ewas, M., Y.Q. Gao, F. Ali, E.M. Nishawy, R. Shahzad, H. Subthain, M. Amar, C. Martin and J. Luo (2017a). RNA-seq reveals mechanisms of SIMXI for enhanced carotenoids and terpenoids accumulation along with stress resistance in tomato. Sci. Bull. (Beijing), 62: 476485.

Ewas, M., E. Khames, K. Ziaf, R. Shahzad, E. Nishawy, F. Ali, H. Subthain, M.H. Amar, M. Ayaad, O. Ghaly and J. Luo (2017b). The tomato DOF daily fluctuations 1, TDDF1 acts as flowering accelerator and protector against various stresses. Sci. Rep., 1: 10299.

Fang, Y., K. Liao, H. Du, Y. Xu, H. Song, X. Li and L. Xiong (2015). A stressresponsive NAC transcription factor SNAC3 confers heat and drought tolerance through modulation of reactive oxygen species in rice. J. Exp. Bot., 66: 6803-6817.

Fu, Y., H. Ma, S. Chen, T. Gu and J. Gong (2018). Control of proline accumulation under drought via a novel pathway comprising the histone methylase CAU1 and the transcription factor ANAC055. J. Exp. Bot., 69: 579-588.

Hahn, A., D. Bublak, E. Schleiff and K.D. Scharf (2011). Crosstalk between $H s p 90$ and $H s p 70$ chaperones and heat stress transcription factors in tomato. Plant Cell, 23: 741-755.

Hanin, M., F. Brini, C. Ebel, Y. Toda, S. Takeda and K. Masmoudi (2011). Plant dehydrins and stress tolerance Versatile proteins for complex mechanisms. Plant Signal. Behav., 6 (10): 1503-1509.

Hare, P.D. and W.A. Cress (1997). Metabolic implication of stress-induced proline accumulation in plants. Plant Growth Reg., 21: 79-102.

Karsten, U. and A. Holzinger (2011). Light, temperature, and desiccation effects on photosynthetic activity, and drought-induced ultrastructural changes in the green alga Klebsormidium dissectum (Streptophyta) from a high alpine soil crust. Microbial Ecology, 63 (1): 51-63.

Egyptian J. Desert Res., 69, Special Issue, 47-67 (2019) 
Laemmli, U.K. (1970). Cleavage of structural proteins during the assembly of the head of bacteriophage T4. Nature, 227 (5259): 680-685.

Lin, J.S., C.C. Kuo, I.C. Yang, et al. (2018). MicroRNA160 modulates plant development and heat shock protein gene expression to mediate heat tolerance in Arabidopsis. Front. Plant Sci., 9: 68.

Loukehaich, R., T. Wang, B. Ouyang et al. (2012). SpUSP, an annexininteracting universal stress protein, enhances drought tolerance in tomato. J. Exp. Bot., 63 (15): 5593-5606.

Lv, A., N. Fan, J. Xie, S. Yuan, Y. An and P. Zhou (2017). Expression of $C d D H N 4$, a novel YSK2-type dehydrin gene from bermudagrass, responses to drought stress through the ABA-dependent signal pathway. Front. Plant Sci., 8: 748.

Marcek, T., K.A. Hamow, B. Végh, T. Janda and E. Darko (2019). Metabolic response to drought in six winter wheat genotypes. PLoS One, 14 (2): e0212411.

Maurel, C., Y. Boursiac, D.T. Luu, V. Santoni, Z. Shahzad and L. Verdoucq (2015). Aquaporins in plants. Physiol. Rev., 95 (4): 1321-1358.

Metzner, H., H. Rau and H. Senger (1965). Untersuchunge zur synchronisierbarkarkeit einzelnerpigmentmangle-mutanten von chlorella. Panta, 65: 186-194.

Mohamed, H.I. and S.A. Akladious (2014). Influence of garlic extract on enzymatic and non enzymatic antioxidants in soybean plants (Glycine max) grown under drought stress. Life Sci. J., 11 (3s): 46-58.

Mohamed, H.I. and H.H. Latif (2017). Improvement of drought tolerance of soybean plants by using methyl jasmonate. Physiol. Mol. Biol. Plants, 23 (3): 545-556.

Moonmoon, S., M.S.A. Fakir and M.T. Islam (2017). Effect of drought stress on grain dry weight, photosynthesis and chlorophyll in six rice genotypes. Sch. J. Agric. Vet. Sci., 4 (1): 13-17.

Mouillon, J.M., S.K. Eriksson and P. Harryson (2008). Mimicking the plant cell interior under water stress by macromolecular crowding: Disordered dehydrin proteins are highly resistant to structural collapse. Plant Physiol., 148: 1925-1937.

Mustari, E., D.S. Diningrat, R. Ratnasih and S.M. Widiyanto (2016). APETALA2 and APETALA3 genes expression profiling on floral development of teak (Tectona grandis Linn f.). J. Plant Sci., 11 (4): 61-68.

Nagahatenna, D.S., P. Langridge and R. Whitford (2015). Tetrapyrrole-based drought stress signalling. Plant Biotechnol. J., 13 (4): 447-459.

Nagaya, S., K. Kawamura, A. Shinmyo and K. Kato (2009). The HSP terminator of Arabidopsis thaliana increases gene expression in plant cells. Plant Cell Physiol., 51 (2): 332. 
Nayer, M.K. and R. Heidari (2008). Drought-induced accumulation of soluble sugars and proline in two maize varieties. World Appl. Sci. J., 3 (3): 448-453.

Okamuro, J.K., B. Caster, R. Villarroel, M. Van Montagu and K.D. Jofuku (1997). The AP2 domain of APETALA2 defines a large new family of DNA binding proteins in Arabidopsis. Proc. Natl. Acad. Sci. USA., 94 (13): 7076-7081.

Orozoco, M.C. and C.A. Ryan (1999). Hydrogen peroxide is generated systemically in plant leaves bywounding and systemin via the octadecanoid pathway. Proc. Natl. Acad. Sci. USA, 96: 6553-6557.

Pastori, G.M. and C.H. Foyer (2002). Common components, networks, and pathways of cross-tolerance to stress. The central role of "redox" and abscisic acid-mediated controls. Plant Physiol., 129 (2): 460-468.

Phukan, U.J., G.S. Jeena, V. Tripathi and R.K. Shukla (2017). Regulation of Apetala2/Ethylene response factors in plants. Front. Plant Sci., 8: 150.

Pureek, A., S. Singla and A. Grorer (1995). Immunolgical evidence for accumulation of two high-molecular-weight (104 \& $90 \mathrm{kDa})$ HSPs in response to ifferent stress in rice and in response to high temperatures stress in diverse plant genra. Plant Mol. Biol., 29: 293-301.

Qian, B., X. Li, X. Liu, P. Chen, C. Ren and C. Dai (2015). Enhanced drought tolerance in transgenic rice overexpressing of maize $\mathrm{C} 4$ phosphoenolpyruvate carboxylase gene via $\mathrm{NO}$ and $\mathrm{Ca} 2 \mathrm{C}^{+}$. J. Plant Physiol., 175: 9-20.

Rahnama, A., K. Poustini, R. Tavakkol-Afshari and Tavakoli A. (2010). Growth and stomatal responses of bread wheat genotypes in tolerance to salt stress. International Journal of Biological Life Science, 6: 216-221.

Rasmy, M., A. Gad, H. Abdelsalam and M. Siwailam (2010). A dynamic simulation model of desertification in Egypt. Egypt J. Remote Sens. Space Sci., 13: 101-111.

Rebolledo, M.C., M. Dingkuhn, A. Clément-Vidal, L. Rouan and D. Luquet (2012). Phenomics of rice early vigour and drought response: Are sugar related and morphogenetic traits relevant?. Rice (N.Y.), 5 (1): 5-22.

Robinson, N.L., C.K. Tanaka and W.J. Hurkman (1990). Time dependent changes in polypeptide translatable mRNA levels caused by $\mathrm{NaCl}$ in barley roots. Physiol. Plant., 78: 128-34.

Sarma, B., N.R. Basumatary, S. Nahar and B. Tanti (2016). Effect of drought stress on morpho-physiological traits in some traditional rice cultivars of Kokrajhar district, Assam, India. Annals of Plant Sciences, 5 (8): 1402-1408.

Satake, M., N. Ikarashi, M. Kagami, N. Ogiue, T. Toda, Y. Kobayashi, W. Ochiai and K. Sugiyama (2010). Increases in the expression levels of aquaporin-2 and aquaporin-3 in the renal collecting tubules alleviate

Egyptian J. Desert Res., 69, Special Issue, 47-67 (2019) 
dehydration associated with polyuria in diabetes mellitus. Biol. Pharm. Bull., 33 (12): 1965-1970.

Schmittgen, T.D. and K.J. Livak (2008). Analyzing real-time PCR data by the comparative C(T) method. Nat Protocols, 3 (6): 1101-1108.

Shahzad, R., P.W. Harlina, C.H. Xie, M. Ewas, E. Nishawy, Z. Pan et al. (2016). Overexpression of potato transcription factor (StWRKYI) conferred resistance to Phytophthora infestans and improved tolerance to water stress. Plant Omics, 9 (2): 149-58.

Sharobeen, S.F., M. El-Attar, Wafaa and A.M. Algaby (1991). The biochemical changes of pre-cooked rice from brown and milled rice. Zag. J. Agric. Res., 18 (9): 121-1031.

Shekoofa, A. and T.R. Sinclair (2018). Aquaporin activity to improve crop drought tolerance. Cells, 7 (9): 123.

Singh, B., S. Kureia and U. Goutam (2018). Milestones achieved in response to drought stress through reverse genetic approaches. F1000 Research, 7: 1311-1318.

Singla, S.L. and A. Grover (1994). Detection and quantification of a rapidly accumulating and predominant $104 \mathrm{KDa}$ heat shock polypeptide in rice. Plant Sci., 97: 23-30.

Stewart, C.R. and A.D. Hanson (1980). Proline accumulation as a metabolic response to water stress. In: 'Adaptation to water and high temperature stress' Turner, N.C. and P.J. Krumer (Eds.). Wiley, New York, pp. 173-189.

Svensson, J., A.M. Ismail, E.T. Palva and T.J. Close (2002). Dehydrins. In: 'Sensing, Signalling and Cell Adaptation' Storey, K.B. and J.M. Storey (Eds.). Elsevier Science, Amsterdam, the Netherlands, pp. 155-171.

Tester, M. and R. Davenport (2003). $\mathrm{Na}^{+}$tolerance and $\mathrm{Na}^{+}$transport in higher plants. Annals of Botany, 91: 503-527.

Toker, C., H. Canci and T. Yildirim (2007). Evaluation of perennial wild Cicer species for drought resistance. Genet. Res. Crop Evol., 54: 1781-1786.

Verma, D.P.S. and Z.L. Hong (1996). Genetically engineered plants resistant to soil drying and salt stress: how to interpret osmotic regulations? Plant Physiol., 110: 1053.

Wehner, G.G., C.C. Balko, M.M. Enders, K.K. Humbeck and F.F. Ordon (2015). Identification of genomic regions involved in tolerance to drought stress and drought stress induced leaf senescence in juvenile barley. BMC Plant Biol., 15: 125.

Wellburn, A.R. (1994).The spectral determination of chlorophylls a and b, as well as total carotenoids, using various solvents with spectrophotometers of different resolution. J. Plant Physiol., 144: 307-313.

Wu, H. (2016). Effect of different light qualities on growth, pigment content, chlorophyll fluorescence, and antioxidant enzyme activity in the red

Egyptian J. Desert Res., 69, Special Issue, 47-67 (2019) 
alga Pyropia haitanensis (Bangiales, Rhodophyta). Biomed. Res. Int., Article ID 7383918.

Xiang, J., X. Chen, W. Hu, Y. Xiang, M. Yan and J. Wang (2018). Overexpressing heat-shock protein OsHSP50.2 improves drought tolerance in rice. Plant Cell Rep., 37 (11):1585-1595.

Xiong, J., L. Zhang, G. Fu, Y. Yang, C. Zhu and L. Tao (2012). Droughtinduced proline accumulation is uninvolved with increased nitric oxide, which alleviates drought stress by decreasing transpiration in rice. J. Plant Res., 125 (1): 155-164.

Xu, J., C. Xue, D. Xue, J. Zhao, J. Gai, N. Guo and H. Xing (2013). Overexpression of GmHsp90s, a heat shock protein 90 (Hsp90) gene family cloning from soybean, decrease damage of abiotic stresses in Arabidopsis thaliana. PLoS One, 8: e69810.

Yan, H.C., C. TieBao, W. Yu and S. BaoHong (2000). Study on the effects of 3 herbicides on the growth of maize seedlings. Plant Protect., 26: 1719.

Yao, J., D. Sun, H. Cen et al. (2018). Phenotyping of Arabidopsis drought stress response using kinetic chlorophyll fluorescence and multicolor fluorescence imaging. Front. Plant Sci., 9: 603.

Yashiba, Y., T. Kiyosure, K. Nakajima, K. Yamaguchi-Shinozaki and K. Shinozaki (1997). Regulation of levels of proline as an osmolyte in plants under water stress. Plant Cell Physiol., 38: 1095-1102.

Zhou, R., X. Yu, C.O. Ottosen et al. (2017). Drought stress had a predominant effect over heat stress on three tomato cultivars subjected to combined stress. BMC Plant Biol., 17 (1): 24.

Egyptian J. Desert Res., 69, Special Issue, 47-67 (2019) 


\section{توصيف الجينوم واسع النطاق للجينات المستجيبة للجفاف يسرع برنامج تربية الفول البلاى الجية}

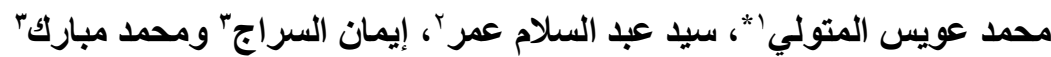

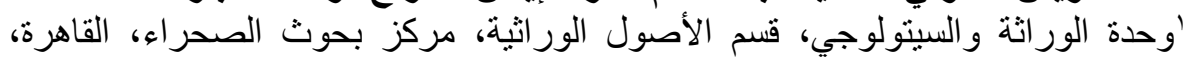

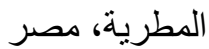
'وحدة تربية النبات، قسم الأصول الور اثية، مركز بحوث الصحر اء، القاهرة، المطرية، مصر 'ققم انتاج المحاصيل، كلية الزر اعة، جامعة العريش، مصر الترك

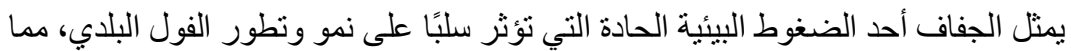

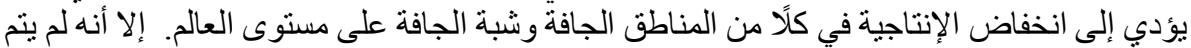

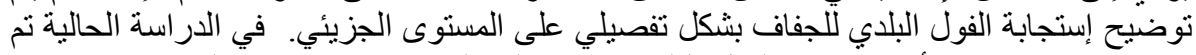

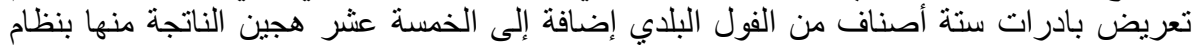

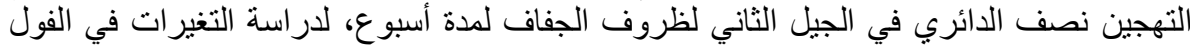

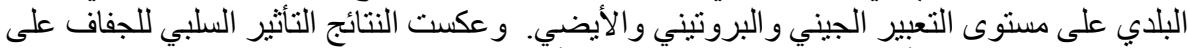

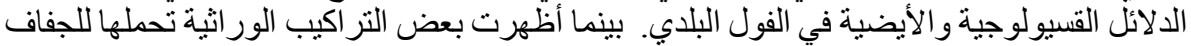

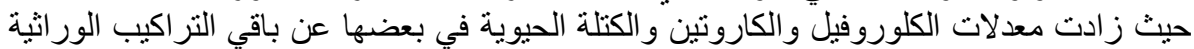

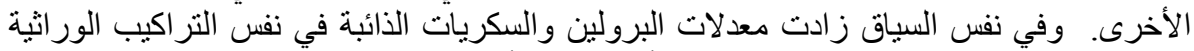

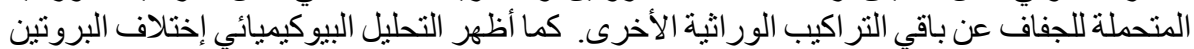

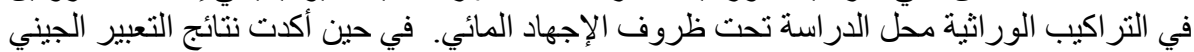

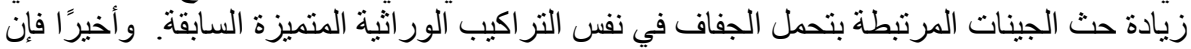

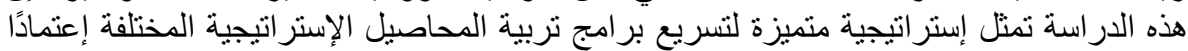

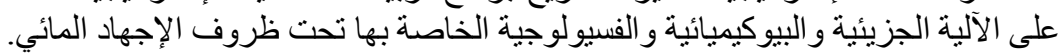

